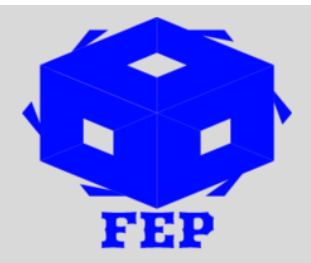

\title{
FOLIAR TRICHOME AND PHYTOCHEMICAL CONSTITUENTS OF JATROPHA GOSSYPIIFOLIA (EUPHORBIACEAE)
}

\author{
Poonam Sethi ${ }^{1}$ \& K.V.K.Viswanath ${ }^{2}$ \\ ${ }^{1,2}$ Assistant Professor, Guru Nanak College, (Autonomous), Chennai, India
}

*Corresponding Author: Poonam Sethi.

Corresponding Author Email: poonam123.73@rediffmail.com

Article Received: 11-05-19 Accepted: 30-07-19

Published: $15-08-19$

Licensing Details: Author retains the right of this article. The article is distributed under the terms of the Creative Commons Attribution-Non Commercial 4.0 License (http://www.creativecommons.org/licences/by-nc/4.0/) which permits non-commercial use, reproduction and distribution of the work without further permission provided the original work is attributed as specified on the Journal open access page.

\section{ABSTRACT}

Leaf of Jatropha gossypiifolia was studied. A detailed pharmacognostical and phytochemical evaluation was done. The study revealed several interesting characters such as anticlinal cell wall pattern $(A C W P)$ and glandular trichomes(GT). Trichomes, glandular unicellular, uniseriate, multi-cellular head with uniseriate stalk. Thus the above-mentioned leaf features are studied as SEM images which are of great taxonomic significance, trichome character is an important data for systematics. Powder Microscopy and phytochemical screening was also studied. The name "Jatropha" is derived from the Greek words "jatros," which means "doctor" and "trophe," meaning "food," which is associated with its medicinal uses. The leaf decoction of this plant is used for treating wounds, sores, sprains, rash and other skin diseases. Presence of high amounts of alkaloids and flavonoids contribute to the medicinal effects that are exhibited.

Keywords: Alkaloids, Epidermal,Glandular, Jatropha Leaf, Stomata,Trichome,SEM.

\section{INTRODUCTION}

India is one of the countries in the world where medicinal plants form the backbone of traditional systems of medicine in India; thousands of tribal communities still use folklore medicinal plants for the cure of various diseases. Indian medicinal plants have been studied for potential source of bioactive compounds. The great interest in the use and importance of medicinal plants in many countries has led to intensified efforts on the documentation of ethno-medical data of medicinal plants Dhar et al. (1968). Medicinal plants are the rich 
source of novel drugs that forms the ingredients in traditional systems of medicine form bioactive principles and compounds in synthetic drugs (Ncube et al., 2008). Jatropha belongs to Euphorbiaceae popularly named as spurge family of the flowering plants, common in the tropics, is a flowering shrub. Jatropha gossypiifolia Linneus is a popularly known worldwide as "bellyache bush" or "black physicnut". It is a pantropical species originating from South America that is cultivated in tropical countries throughout the world.

Jatropha species are used in traditional medicine to cure various ailments in Africa, Asia, and Latin America or as ornamental plants and energy crops .Several known species from genus Jatropha have been reported for their medicinal uses, chemical constituents, and biological activities.

\section{MATERIALS AND METHOD}

The whole plant was collected from Guru Nanak College campus, Chennai of Tamilnadu, India identified by botanist of CSMDRIA Chennai.(Figure I) Microscopical characters were studied (Evans, Trease and Evans, 1997). Epidermal tissues were studied from paradermal sections of lamina in surface view under Scanning Electron Microscope (SEM).

The leaf was dried, powdered and studied under the compound microscope.

Ten grams of the leaf powder was extracted with $100 \mathrm{ml}$ of hexane, chloroform, ethyl acetate, ethanol and kept for 48 hours. The samples were filtered and the filtrate was dried in a lyophilizer. Different extracts were screened for the presence of phenols, flavonoids, tannin, saponin, alkaloids and steroid by using standard protocols (AOAC, 1990; and Harbone 1973).

\section{I) SEM ANALYSES OF LEAF LAMINA}

\section{RESULTS}

Trichomes were clearly distinguished as unicellular uniseriate, glandular trichomes with multicellular head and wavy anticlinal epidermal wall cells. (Figure II)

\section{II) POWDER MICROSCOPY}

Epidermal appendages trichomes are unicellular and uni-seriate, Glandular trichomes are unicellular and multi-cellular head with uniseriate stalk, Epidermal cells are wavy Xylem vessels showed spiral and pitted thickening, Sclereids and stone cells are found with pitted thickening parenchyma cells with brown contents are present. .(FigureIII)

\section{III) PHYTOCHEMICAL SCREENING}

Phytochemical screening revealed the presence of phenols, flavones, glycosides in the ethyl acetate extract of $J$. gossypifolia leaf (Table 1). Presence of these phytochemical constituents might be responsible for the therapeutic properties exhibited by this plant.

\section{REFERENCES}

AOAC. (1990). Official methods of analysis. $16^{\text {th }}$ ed. Association of Official Analytical Chemists. Washington. D.C. 
Dhar, M.L., Dhar, M.M., Dhawan, B.N., \& Ray, C. (1968). Screening of Indian plants for biological activity - Part I. Indian Journal of Experimental Biology, 6, 232-247.

Trease, \& Evans. (1997). Pharmacognosy (14th Ed), Harcourt Brace and Company. Asia Pvt. Ltd. Singapore

Harborne, J.B. (1973). Phytochemical methods. Chapman and Hall Ltd., London.

Ncube, N., Afolayan, S.A.J. and Okoh, A.I. (2008). Assessment techniques of antimicrobial properties of natural compounds of plant origin: Current methods and future trends. African Journal of Biotechnology, 7, 1797-1806.

\section{TABLES}

Table 1: Phytochemical properties of the leaf of * Jatropha gossypiifolia

\begin{tabular}{|c|c|c|c|c|c|}
\hline S.No & Compound & $\begin{array}{c}\text { Hexane } \\
\text { extract }\end{array}$ & $\begin{array}{c}\text { Ethanol } \\
\text { extract }\end{array}$ & $\begin{array}{c}\text { Ethyl } \\
\text { acetate } \\
\text { extract }\end{array}$ & $\begin{array}{c}\text { Chloroform } \\
\text { extract }\end{array}$ \\
\hline $\mathbf{1}$ & Alkaloids & - & - & + & - \\
\hline $\mathbf{2}$ & Steroids & - & - & - & + \\
\hline $\mathbf{3}$ & Tannin & - & - & + & + \\
\hline $\mathbf{4}$ & Saponin & - & - & - & + \\
\hline $\mathbf{5}$ & Flavonoids & - & + & + & - \\
\hline $\mathbf{6}$ & Phenols & - & - & + & + \\
\hline
\end{tabular}

*Shade dried powdered material. (+) presence and (-) absence

The above parameters help in identifying the species and to establish the authenticity of this plant and can possibly help to differentiate the drug from its other adulterants. 


\section{FIGURES}

\section{I) EXPERIMENTAL PLANT}

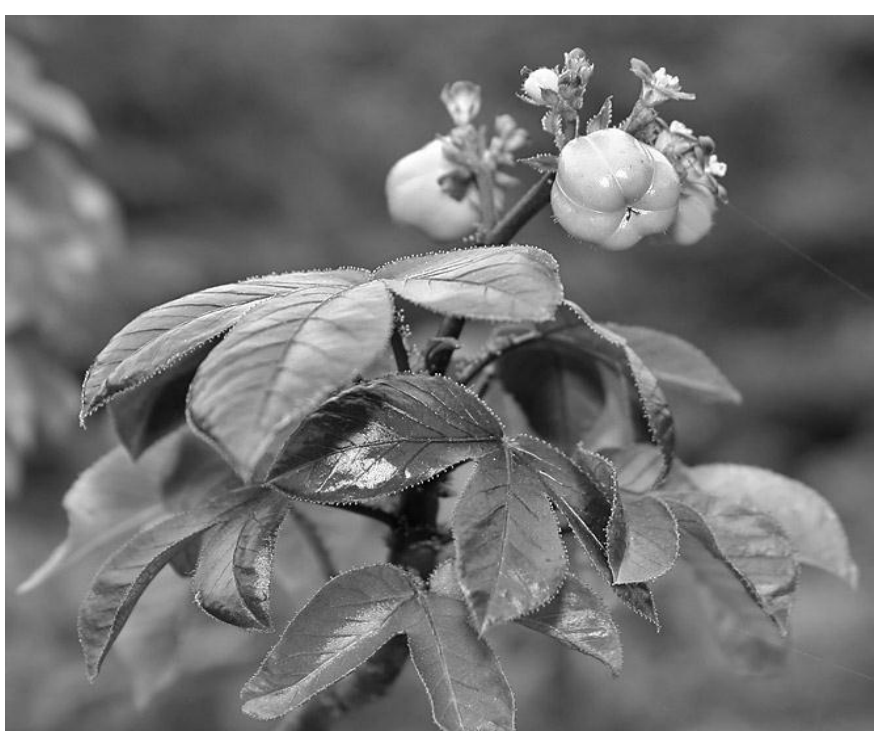

II) SEM IMAGES OF THE EXPERIMENTAL PLANT :LEAF PART
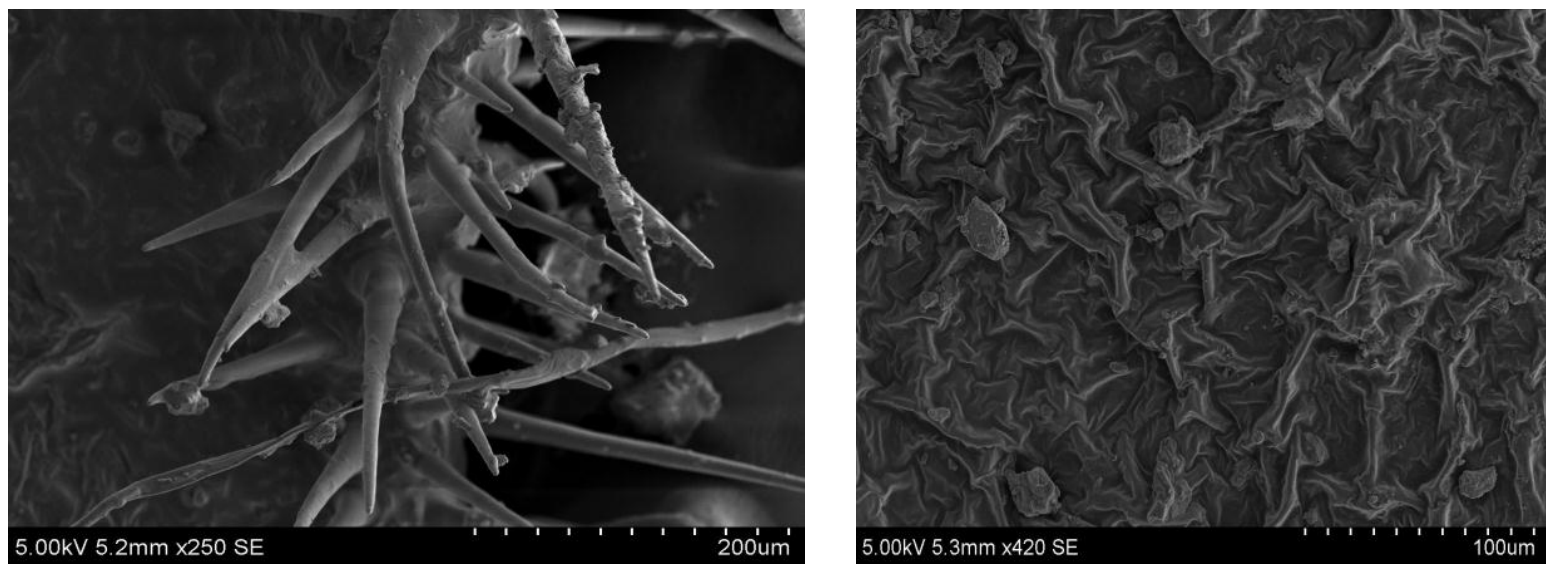

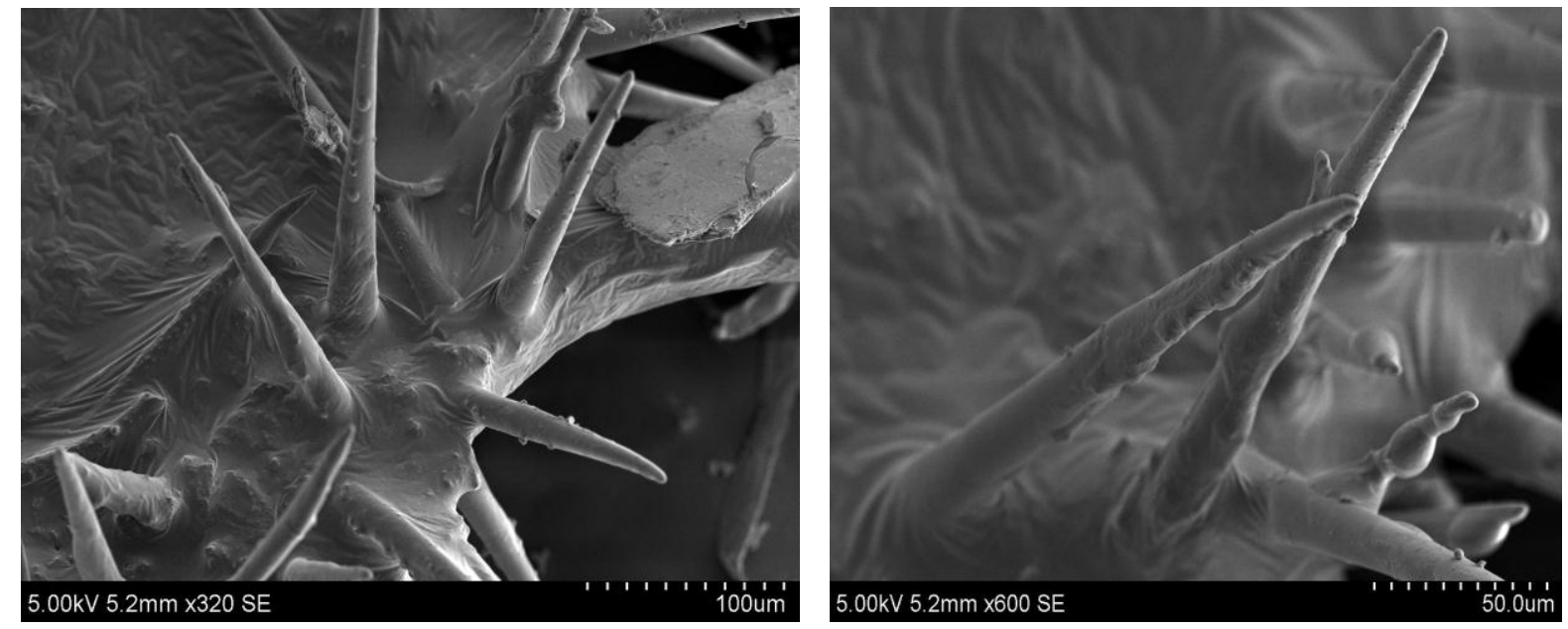

III) POWDER MICROSCOPY OF THE EXPERIMENTAL PLANT :LEAF PART

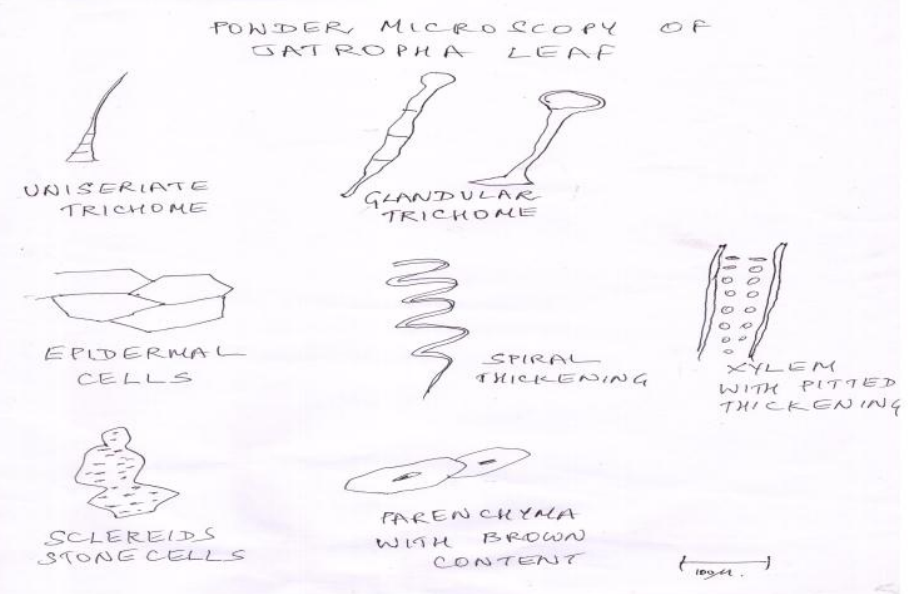

